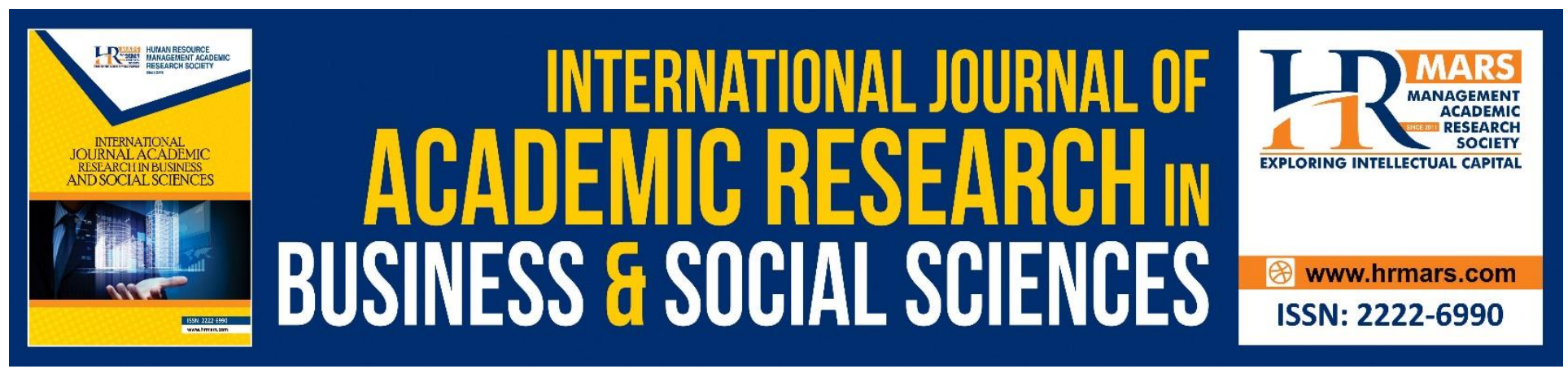

\title{
Career Transition Program for Special Need Students: A Preliminary Survey
}

Kama Shaffeei, Abdul Rahim Razalli, Mohd Hafiz Mohd Hanif

To Link this Article: http://dx.doi.org/10.6007/IJARBSS/v10-i9/7863

DOI:10.6007/IJARBSS/v10-i9/7863

Received: 30 June 2020, Revised: 21 July 2020, Accepted: 18 August 2020

Published Online: 12 September 2020

In-Text Citation: (Shaffeei, Razalli, Hanif, 2020)

To Cite this Article: Shaffeei, K., Razalli, A. R., Hanif, M. H. M. (2020). Career Transition Program for Special Need Students. A Preliminary Survey. International Journal of Academic Research in Business and Social Sciences. 10(9), 736-746.

Copyright: (c) 2020 The Author(s)

Published by Human Resource Management Academic Research Society (www.hrmars.com)

This article is published under the Creative Commons Attribution (CC BY 4.0) license. Anyone may reproduce, distribute, translate and create derivative works of this article (for both commercial and non-commercial purposes), subject to full attribution to the original publication and authors. The full terms of this license may be seen

at: http://creativecommons.org/licences/by/4.0/legalcode

Vol. 10, No. 9, 2020, Pg. 736 - 746

http://hrmars.com/index.php/pages/detail/IJARBSS

JOURNAL HOMEPAGE

Full Terms \& Conditions of access and use can be found at http://hrmars.com/index.php/pages/detail/publication-ethics 


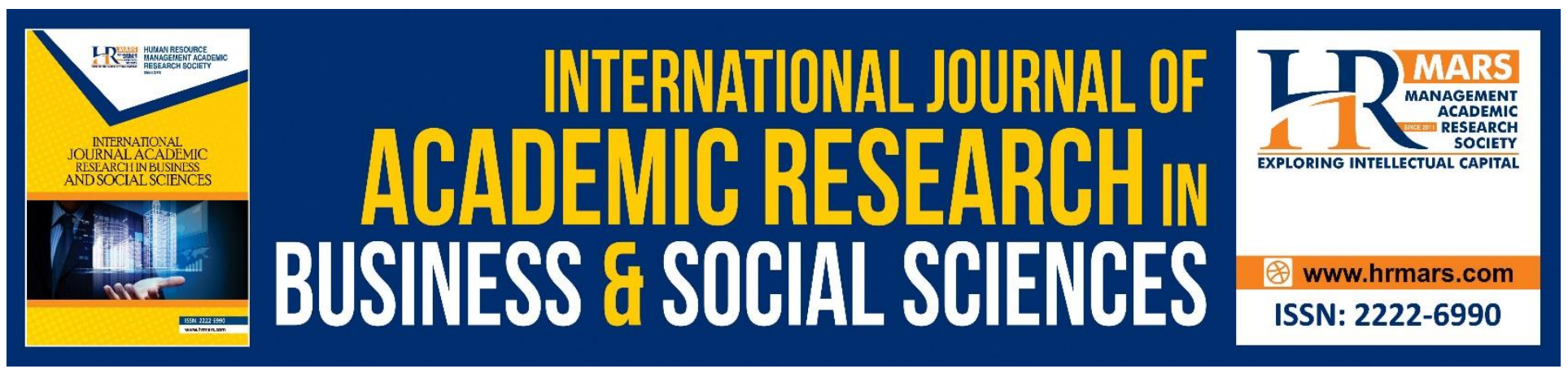

\title{
Career Transition Program for Special Need Students. A Preliminary Survey
}

\author{
${ }^{1}$ Kama Shaffeei, ${ }^{2}$ Abdul Rahim Razalli ${ }^{3}$ Mohd Hafiz Mohd Hanif \\ Faculty of Human Development, Sultan Idris Education University, Perak, Malaysia. \\ Email: ${ }^{1}$ Kama@fpm.upsi.edu.my, ${ }^{2}$ r.rahim@fpm.edu.my ${ }^{3}$ mohd_hafiz@fpm.upsi.edu.my
}

\section{Abstract}

The purpose of this study is to analyse the needs of the Special Needs Career Transition Program in school. The Special Needs Students Career Transition Program was implemented to prepare the Special Needs Students with basic and vocational skills as well as individual employment aspects. The objective of the study were to (1) Identify the level of preparedness among Special Education Teachers in the implementation of the Career Transition Program for Special Needs students in the Special Education Integrated Program (SEIP), (2) Identify the Special Needs students preparedness level in implementing the Career Transition Program at SEIP, and (3) Identify the policy compliance and guidelines in the implementation of the Career Transition Program at SEIP. The research methodology uses the literature review method and case study to answer the research questions. The sample was used to review the case studies of implementation of the Career Transition Program in schools and the literature review was analysed thematically according to the objectives of the study. The findings show that the preparedness of special education teachers needs to be enhanced with the implementation of the basic skills courses and the Malaysian Skills Certificate (MSC). Special Needs students (SNS) need to be trained and equipped with 3 basic skills (Reading, Writing, Counting), Vocational Basic skills, Basic self-management skills, Social skills, Communication skills, Problem solving skills, Basic technology skills and deep interest in the field before participating in the Career Transition Program. Meanwhile, the aspects of compliance with the Career Transition Program Guidelines are well-respected and need to be further enhanced among school administrators. It is proposed in the future, all the Special Education teachers must have the Malaysian Skills Certificate and Vocational Skills courses in order to enhance their competence. SNS should be educated with a high degree of self-determination and a deep interest in the areas of interest. Systematic Career Transition Program modules and frameworks need to be developed to explain SNS direction upon completion of the Career Transition Program. It is hoped that this study will provide ideas and contributions in streamlining and implementing the Career Transition Program in the future.

Keywords: Career Transition Program, Special Needs Student, Special Education Integrated Program, Special Education Teacher, Policy Compliance. 
INTERNATIONAL JOURNAL OF ACADEMIC RESEARCH IN BUSINESS AND SOCIAL SCIENCES Vol. 10, No. 9, 2020, E-ISSN: 2222-6990 @ 2020 HRMARS

\section{Introduction}

The Career Transition Program is a process of providing Special Needs Students (SNS) in training and skills in the real world of work. This program is essential to ensure SNS is ready for employment after leaving school.

Multiplexed SNS need to be exposed to natural talent as a process of self-realization in real life (Shaffeei, 2012; 2007). In early-stage, starting from form one, SNS need to be able to diagnose and refine their potential and basic skills before attending training for Basic vocational skills or Malaysian Skills Certificate courses in the Special Education Integrated Program (SEIP) at their respective schools (Shaffeei, 2019).

SNS marketability is an important factor in developing human capital that contributes to national development (MOE, 2019). The post-secondary SNS market needs to have basic skills in the areas of basic skills, personal qualities, interpersonal skills and tendency to interest in selected fields of work (Ministry of Education Malaysia, 2018).

\section{Background}

The career-training process began in 2003 in the Life Skills subject for students with learning disabilities in the Learning Disabilities Classroom Program (LDCP). Basic skills training introduced in the Life Skills subject consists of cooking basics, sewing basics, basics, basics, handicrafts, car wash and bicycle and motorcycle maintenance.

In 2006, the Special Vocational Curriculum was introduced by the MOE to assist the SNS in SEIP towards career preparation. There are six components of cooking, sewing, agriculture, handicraft, service and maintenance with the basic amenities available in the school.

In 2015, the Special Education Secondary Curriculum (SESC) was introduced by the MOE in an effort to uphold the education equality for the SNS and 2018 is in the second tier and will end in the fifth grade in 2021. This Education Opportunity opens up the opportunity for schools and SNS to choose the right skills to ensure SNS is skilled, self-reliant and successful.

In 2019, MOE will introduce the Career Transition Program to assist SNS in SEIP from form one to five. The program is implemented to SNS based on the skills and courses provided by schools, skill centers, industry and Non-profit Government Organizations (NGO). The objectives of the Career Transition program implemented over five years at the SEIP so that SNS will have sufficient skills in the field of employment to suit their level of ability.

\section{Literature Research}

The School to Career Program (Buntat, 2000) was introduced to provide students with training opportunities before they start work. It has been implemented for all upper secondary students from form four to five. The program focuses on students who are not well-versed in academics so that they gaining the work skills while in school and the job opportunities after graduation.

In this regard, SNS Learning Disabilities in particular need to be prepared with various skills for the future of their careers (Shaffeei, 2007; Nasir, 2016). Multipurpose SNS at SEIP need to be equipped 
INTERNATIONAL JOURNAL OF ACADEMIC RESEARCH IN BUSINESS AND SOCIAL SCIENCES Vol. 10, No. 9, 2020, E-ISSN: 2222-6990 @ 2020 HRMARS

with a wide range of vocational and personal skills so that they can compete with others in the job market. Therefore, the Skills Curriculum needs to be developed for the SNS at SEIP based on their ability (Isa, 2008). As a result, the vocational skills base courses and the Malaysian Skills Certificate (MSC) courses at the SEIP (MOE, 2015) are expected to assist the SNS readiness. However, the school needs to ensure that in terms of physical and infrastructure facilities, teachers' skills and SNS readiness contribute to the success of the SEIP curriculum and Career Transition Program. In addition, School-based Training needs to be applied to the SNS Learning Disabilities in SEIP (Shaffeei, 2010; Isa, 2008). This training is carried out in conjunction with the teaching and facilitating process of teachers in schools. Teacher knowledge and understanding are essential for successful training and the Career Transition Program can be applied to SNS. Therefore, School-based Life Skills Training and Basic Skills Training should be practiced in learning at SEIP (Shaffeei, 2019).

According to Nasir (2016), the Career Transition Program helps SNS to prepare for the real world of work. Schools need to play an important role by working collaboratively through industry and skills centres. These skills training indirectly helps SNS in getting a job later.

\section{Problem Statement}

Special Education teacher preparedness factors play an important role in implementing the Career Transition Program in schools. According to Yaakub \& Hamzah (2019), the Special Education teacher knowledge, attitude and skills are at a moderate level. Lokey \& Dali (2016) found that the level of commitment among Special Education teachers declines when it comes to administering leadership. This shows that the Special Education teachers' readiness in implementing the Career Transition Program needs to be strengthened to ensure the SNS has the skills and competencies expected in the future.

As such, SNS readiness factors in the Career Transition Program require the support of all parties. According to Kamela \& Alib (2016), students' ability to work are very low. This is because the problem of mastering basic skills is at a low level and needs to be increased. Issues of low capacity and physical capacity of SNS, based on public opinion (Daros et al., 2012) contributed to this study. Factors lack of SNS personal skills in line with employers, wishes (Abdullah et al., 2015) also influence this study. The compliance factors and guidelines for the Career Transition Program introduced by MOE in 2019 are also the focus of this study. In order to implement this program, school administrators need to give teachers the opportunity to make the best decision in Teaching and Learning (T \& L), (Yusoff \& Saidin (2016). Teachers need to be given the freedom that encompasses the achievement of the school's objectives and mission of the SNS. There is no specific guidance on implementing the Career Transition Program as schools are still unable to perform well (Masadayu et al., 2018; Kamela, \& Alib, 2016). However, the existence of these guidelines can help schools realize their SNS. This indicates that the need for skills training for SNS in the Career Transition Program meets the requirements of employers in the industry.

Therefore, factors of teacher readiness, SNS readiness and adherence to SNS Career Transition Program Guidelines in this study should be considered and analysed to meet the needs of SNS, Parents, schools and industry.

\section{Research Objective}

1. Identify the level of preparation among Special Education teachers in the implementation of the Career Transition Program for special needs students at SEIP. 
INTERNATIONAL JOURNAL OF ACADEMIC RESEARCH IN BUSINESS AND SOCIAL SCIENCES Vol. 10, No. 9, 2020, E-ISSN: 2222-6990 @ 2020 HRMARS

2. Identify the level of Special Needs Students in the implementation of the Careers Transition Program at SEIP.

3. Identify policy compliance and guidelines in the implementation of the Career Transition Program at SEIP.

\section{Study Framework}

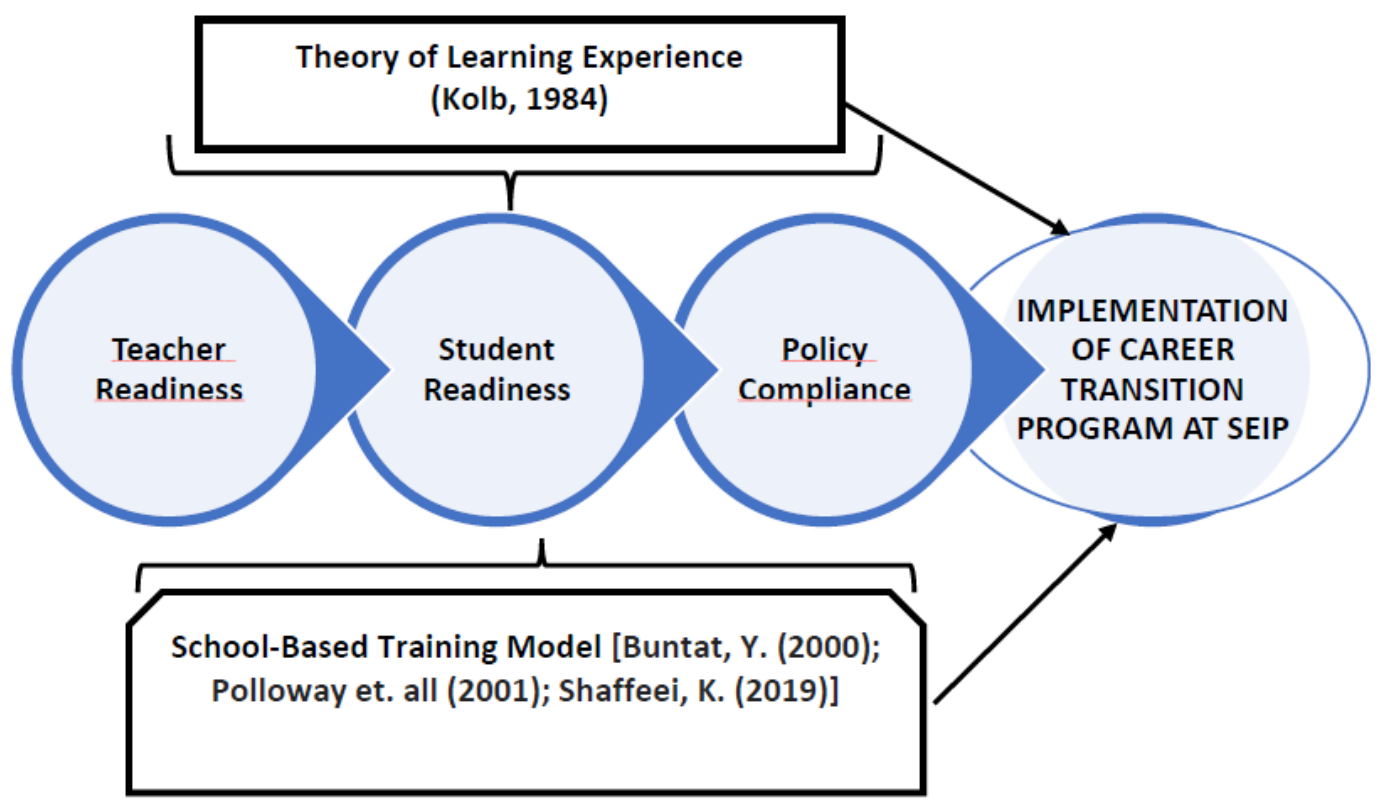

Figure 1: Study Framework Implementation of Career Transition Program at Special Education Integrated Program (SEIP)

Figure 1 shows the variables in the implementation of the Career Transition Program toward Special Need Students in schools. The variables involved were teacher readiness, SNS readiness and school policies and guidelines. The School-Based Training Model (Buntat, 2000; Polloway et al., 2001; Shaffeei, 2019) was used in this study. Meanwhile, Theory of Learning Experience (Kolb, 1984) was applied to review the implementation of the SNS Career Transition Program in schools.

\section{Research Methodology}

The study was conducted through a literature review and case study to identify teacher readiness, SNS readiness and policy compliance implemented in the transition program to the special needs student careers at SEIP. Lebar (2007) stated that case studies are appropriate to get in-depth answers to any questions that students want to study. The research sample is intended to be based on previous studies and a case study conducted at the SEIP of a secondary school that implementing the Career Transition Program in the state of Selangor. 
INTERNATIONAL JOURNAL OF ACADEMIC RESEARCH IN BUSINESS AND SOCIAL SCIENCES Vol. 10, No. 9, 2020, E-ISSN: 2222-6990 @ 2020 HRMARS

\section{Findings}

Findings of Study 1: Preparation of special education teachers in implementing career transition programs in SEIP

a) Literature Review

Teachers are able to train their SNS in preparation for entry into the work environment (Worrell \& Taber, 2009). Teachers also need to prepare SNS for job opportunities, curricular and suitability of activities to be developed in preparation for change, technological diversification and lifelong learning (Elleven et al. 2006). According to Ismail (2018), the responsibility of a Special Education teacher is to provide as much knowledge and skills as possible for the SNS.

\section{b) Case Study}

All SEIP teachers are given basic skills courses in line with the development of a curriculum designed to enhance SNS skills. High school students have designed, researched and collaborated with agencies and various disciplines and implemented programs for student skills to work and self-reliance.

Findings of study 2: Preparing students with special needs in implementing career transition programs in SEIP.

a) Literature Review

Generic skills need to be applied to SNS as they are important for them as a preparation to work (Nasri et al., 2010). These skills should include self-management skills, personal or individual skills, basic information and computer technology skills as well as selected job scope skills. According to the study of Yusuf et al. (2013) stated that vocational education is one of the efforts to develop the SNS's ability to acquire skills that enable them to obtain employment. Vocational education in SNS Learning Disabilities helps to prepare them for the world of work after graduation (Shaffeei, 2019; Nasir, 2016; Daros et al., 2012; Jones \& Williams, 2011; Paul, 2011; Ofoegbu \& Azarmsa, 2010; Worrell \& Taber, 2009; Isa, et al., 2009; Dupoux, 2008 ).

\section{b) Case Study}

According to the survey of school cases, 54 SNS were involved in various basic skills training towards the Career Transition Program (90\%). Various skills training are being carried out such as; Culinary and Pastry (17 people), Automotive- Motorcycle Repair (3 people), Sewing (6 people), Cake Decoration (1 person), Creative / Craft Project (7 people), Waitress (12 people) and 9 SNS members involved in the Career Transition Program: Top Secondary Industry Apprentice (TSIA) with industry collaboration.

\section{Findings of Study 3: Compliance with Implementation of Career Transition Program Guidelines at SEIP}

a) Literature Review

Abdullah, N \& Mohd Yasin (2014) stated that the Alternative Vocational Skills Curriculum and School Skills (Career) in Special Education Curriculum for Learning Disability in Secondary school should be applied to SNS. According to the study of Abdullah et al. (2015) on vocational education as the basis of SNS with Learning disability career path also prove that education continuity and employment opportunities have not been effectively implemented between the MOE and the Ministry of Human Resource $(\mathrm{MOH})$. Furthermore, the 1\% Job Opportunity for the disabled in the public service opens 
INTERNATIONAL JOURNAL OF ACADEMIC RESEARCH IN BUSINESS AND SOCIAL SCIENCES Vol. 10, No. 9, 2020, E-ISSN: 2222-6990 @ 2020 HRMARS

up employment opportunity for the disabled. In addition, MOE (2016) implemented the Special Education Secondary School Standard Curriculum focusing on the subject of Vocational Basic Skills and Malaysian Skills Certificate (MSC) courses at SEIP.

\section{b) Case Study}

The findings of the case study shows that the school implemented all of the MOE instructions including implementing the SNS Career Transition Program. Furthermore, the school received good support from the Parents and Teachers Association (PTA) and SNS parents. The local industry also supported the SNS's placement in work training such as Tan Chong Motor (Automotive), Nora Delight (Bakery), SPA Beans (SPA Therapy) and co-training and short courses at the nearby Community College.

\section{Discussion}

Discussion 1: The preparation of special education teachers in the implementation of the Career Transition Program at SEIP

The findings show that teachers need to have high knowledge and skills in implementing the Career Transition Program. According to Blackmon (2008) teachers need to provide Individual Education Plan (IEP) services based on their strengths, interests and goals after completing their schooling. Rahmada, et al. (2019), on the other hand, states that the level of teacher's skills needs to be improved in ensuring that students with special needs master the skills.

In case studies in schools, there is demand for skills courses such as Malaysian Skills Certificate (MSC) to all teachers involved to help the teaching and learning process run smoothly in accordance with the demand and support of the Skills Development Department and the $\mathrm{MOH}$.

Indirectly, teachers should equip themselves with the knowledge, understanding and vocational skills to guide SNS in mastering the basic vocational skills and essential skills of the Malaysian Skills Certificate.

\section{Discussion 2: Preparing students with special needs in implementing Career Transition Program at SEIP}

SNS should have the basics of 3 Skills (Reading, Writing and Calculating) and Vocational Skills in preparing themselves for the Transition Skills Training and Career Program (Shaffeei, K., 2019). The findings show that SNS level in the field of employability skills is low (Samian, Ali \& Buntat, 2013). In addition, the employability skills acquired by SNS in vocational education do not necessarily meet the needs of their employers (Yusuf, A. M., Ali, M. M, \& Salleh, A. M. 2013). Therefore, SNS needs support in maintaining the skills acquired in schools in line with the demands of the job market. The study of Mohamed Nor, N. and Mohd Yasin, M., H. (2018) shows that the level of involvement of the SNS parents is moderate and needs to be improved. The role of parents is important in helping and supporting SNS readiness for real career.

Meanwhile, the case study at school shows the need for basic skills training for all SNS before joining the Career Transition Program. This shows that SNS early readiness is crucial to the Career Transition Program. 
INTERNATIONAL JOURNAL OF ACADEMIC RESEARCH IN BUSINESS AND SOCIAL SCIENCES Vol. 10, No. 9, 2020, E-ISSN: 2222-6990 @ 2020 HRMARS

Discussion 3: Compliance with the implementation of Career Transition Program Guidelines at SEIP. Career Transition Programs need to be systematically implemented to assist SNS who are in the middle of schooling (Yaakub, \& Hamzah, 2019). Knowledge and understanding of the implementation of the secondary curriculum in Malaysia needs to be enhanced and should be geared towards providing the SNS with vocational skills (Shaffeei, 2019; Daros et al., 2012; Peter et al., 2010; Isa et al., 2009) .As a result, the SNS Career Transition Program Guidelines are expected to serve as a guide for implementation in schools.

Findings of the case study at school shows the high school's knowledge and understanding of the implementation of the Career Transition Program to SNS. This finding shows a high level of awareness at the school level to ensure the program works as required by the MOE.

\section{Proposal}

The preparedness of Special Education Teachers in this Career Transition Program is essential to ensure that it works as required by MOE. Teachers needs to know and master all aspects of Special Needs Career Transition Program. Teachers also need to be proficient in skills to facilitate teaching and learning sessions at SEIP. An element of Multitasking skills need to be present in the teaching of SNS teachers.

In this regard, SNS needs to have a deep interest in the Career Transition Program to facilitate teacher training and teaching sessions. SNS also needs to be prepared in the self-career aspect of the Career Transition Program which is basic self-management skills, social skills, communication skills, problem solving skills, basic skills technology and deep interest in the field. SNS preparation is essential to successful Career Transition Program by having that skill set.

As such, the Compliance Aspect and the Career Transition Program Guidelines require the knowledge and understanding of school administrators to disseminate this information. Creating school collaboration with parents, communities and the job industry needs to be established. Schools and industry partnerships need to be formed to give SNS opportunities to work in the right field. In addition, clear and well-organized Career transition Program Modules and frameworks should be provided to assist in compliance with the policies and guidelines. Therefore, it is clear that the proposed study is expected to assist in the successful implementation of the Career Transition Program for SNS in schools.

\section{Conclusion}

The Career Transition Program is a platform for all SNS in preparing for the real workforce in all schools around the world. SNS needs to be given the space and opportunity to contribute their energy and skills to their potential (MOE, 2016). It is important for SNS to help them get into the field of work that interests them and to their full potential. The need for a well-organized of Career Transition Program helps schools, SNS, Parents and Communities in terms of implementation and future success implications.

\section{Acknowledgement}

A special thank you to the Sultan Idris University of Education, Tanjong Malim, Perak for sponsoring the research for the Special University Research Promotion Grant (SURG) Project, Research Code: 2020-0019-106-01. 
INTERNATIONAL JOURNAL OF ACADEMIC RESEARCH IN BUSINESS AND SOCIAL SCIENCES Vol. 10, No. 9, 2020, E-ISSN: 2222-6990 @ 2020 HRMARS

\section{Co-Author}

Associate Professor of Haji Dr Abdul Rahim Razalli, Senior Lecturer in the Department of Special Education, Faculty of Human Development, UPSI and Dr Mohd Hafiz Mohd Hanif, Senior Lecturer in the Department of Education, Faculty of Human Development, UPSI.

\section{References}

Abdullah, N., \& Yasin, M. H. (2014).Requirements for Implementing a Special Vocational Curriculum (SVC-Special) Student Learning Disabilities in the Career Preparedness Course. UKM-UPI International Postgraduate Education Seminar Bangi: National University of Malaysia. 1 - 7.

Abdullah, N., Yasin, M. H., Deli, R. A. A., \& Abdullah, N. A. (2015).Vocational Education as a Career Pathway for Students with Learning Disabilities: Issues and Obstacles in the Implementation.International Journal of Education and Social Science.2 (3).98 - 104.

Blackmon, D. (2008). Transition to adult living: An information and Resource Guide. California Services for Technical Assistance and Training (CaISTAT California Department of Education 2008).

Buntat, Y. (2000).School to Career Program.

Dupoux, E. (2008). General or Vocational Curriculum: LD Preference.InternationalJournal of Special Education. 23 (3), 39 - 47.

Elleven, R., Wircenski, M., Mircenski, J., \& Nimon, K. (2006).Curriculum Based Virtual Field Trips:Career Development Opportunities for Students with Disabilities.The Journal for Vocational Special Needs Education.4 - 11.

Ismail, H. (2018). Empowering the SNS Transition into Career.https://www.pend Educational.com.my/2018/02/02/making-transition-mbk-ke-alam-research/.Available online April 22, 2020.

Shah, J. S. M., Alias, A., Rahim, N. R., Ishak, N. H. (2018).The level of readiness of a special education teacher in implementing a special needs student learning transition program. International Conference on Special Education in Southeast Asia Region 8th Series 2018

Jones, B. A., \& Williams, K. L. (2011).Perceptions of Vocational Training with Elementary Special Education Students: A Case Study.International Journal of Special Education. 26 (1), 125 - 134.

Kamela, N. F., \& Alib, M. (2016).Factors influencing the effectiveness of a special needs student learning transition program.International Conference on Learning Innovation and Quality Education 1st Series 2016.

Kolb, D. (1984). Experiental Learning Theory.

Lebar, O. (2007). Qualitative Research Methods.Publisher of UPSI Tanjong Malim.

Lokey, A., \& Dali, M. H. (2016). The relationship between the transformational leadership of the headmaster and the commitment of integrated special education teachers in Kedah. January 2016 Journal of Educational Leadership, no. 3, Issue 1.

Isa, M. H., \& Abdul Kadir, S. (2013). Comparison of Vocational Skills Needs Special Education Students Integrate Daily Secondary School with Vocational Special Education Secondary School.Postgraduate Seminar in Education. Bangi: Universiti Putra Malaysia. 400 - 406.

Daros, M., Nordin, M. S., \& Saud, M. S. (2012).Students with Special Needs and Learning Disabilities from Schools to Careers.Journal of Social Science. 5 (1), 42 - 46.

Isa, M. Z. (2008).Analysis of Vocational Skills Requirements for Students with Learning Disabilities.Thesis of Special Education in National University of Malaysia. 
INTERNATIONAL JOURNAL OF ACADEMIC RESEARCH IN BUSINESS AND SOCIAL SCIENCES

Vol. 10, No. 9, 2020, E-ISSN: 2222-6990 @ 2020 HRMARS

Ministry of Education Malaysia. (2019).Guidelines for the Transition to Career Special Needs Program.Special Education Division.

Ministry of Education Malaysia. (2018).Vocational Skills Course Study in Vocational Special Education Secondary School for Special Needs Pupils.Special Education Division.Not published.

Ministry of Education Malaysia. (2003).Classroom Curriculum Syllabus Impaired in Primary and Secondary Learning.Department of Special Education.

Ministry of Education Malaysia. (2006).Special Vocational Subjects (SVS-Special), Department of Special Education.

Ministry of Education Malaysia. (2015).Special Education Secondary Curriculum.Curriculum. Curriculum Development Division.

Ministry of Education Malaysia. (2016).Preliminary Report of the Malaysian Education Development Plan (2013-2025).

Nasir, M. S. I. (2016).Implementation of the Transition to Career Program. University of Technology Malaysia. Skudai, Johor.

Nor, M. N., and Yasin, M. H. (2018). Involvement of special needs parents in implementing career transition programs.Journal of Educational Research Volume 19.

Isa, M. Z., Salleh, N., Mustapha, R., \& Yassin, M. H. (2009).Analysis of the Needs of Learning Disabilities (LD) Vocational Education Curriculum Needs in Malaysia.Malaysian Education Deans' CouncilJournal. 3 (2), 87- 97.

Yusoff, M. S., \& Saidin, K. (2016).School climate level, teacher commitment level and the relationship between school climate and teacher commitment in Machang, secondary schools. Proceeding of ICECRS, 1 (2016) 635-646.

Ofoegbu, N. E., \& Azarmsa, R. (2010).Impact of The Special Education Vocational Education Program (VEP) On Student Career Success.International Journal of Special Education. 25 (2), 34 - 46.

Paul, S. M. (2011). Outcomes of Students with Disabilities in a Developing Country: Tobago.International Journal of Special Education.26 (3), $194-211$.

Peter, C. J., Emeliana, E., \& Sofi, M. N. (2010).Development of the Technical and Vocational Special Education Curriculum.Completed April 14, 2020, from p. 1 at http://eprints.utm.my/14941/1/Development_Education_Education_and_Vocational.pdf.

Polloway, E. A., Patton, J. R., \& Serna, L. (2001).Strategies for Teaching Learners with Special Needs.7th ed. Upper Saddle River, N.J: Merrill / Prentice Hall.

Rahmada, S. R., Mouthie, A. N., and Zulkeflic, Z. Z. (2019).Preparedness of the North Zone Community College of Malaysia for a special learning program for Learning Diasabilities (LD) students.International Conference on Special Education in Southeast Asia Region 9th Series 2019.

Samian, S. S., Ali, K. M., \& Buntat, Y. (2013).Employers' Perceptions of Workers with Disabilities in Organizations in the State of Johor [electronic version].Completed April 13, 2020, from ms1. at http://educ.utm.my/wpcontent/uploads/2013/11/491.pdf.

Shaffeei, K. (2007).The Future and Career of LDs Students.Bachelor of Education (Special Education) Thesis Project Report. Sultan Idris Education University. Not published.

Shaffeei, K. (2010).Special Vocational Subject Assessment (SVS-Special) Field of Maintenance.A Case Study at a Sabak Bernam District School.Master Thesis (Special Education) Project Report.Sultan Idris Education University. 
INTERNATIONAL JOURNAL OF ACADEMIC RESEARCH IN BUSINESS AND SOCIAL SCIENCES

Vol. 10, No. 9, 2020, E-ISSN: 2222-6990 @ 2020 HRMARS

Shaffeei, K. (2019). Development of Vocational Skill Screening Instruments (VSSI) Special Needs Students Learning Disabilities (SNSLD) in Special Education Integrated Program (SEIP) for Preparing for Malaysian Skills Certificate. Master's Degree in Doctor of Education (Special Education).Sultan Idris Education University.

Worrell, J. L., \& Taber, M. (2009).Special Education Practices in China and The United States: What is To Come Next? International Journal of Special Education.24 (3), 132 - 142.

Yaakub, M. Y., \& Hamzah, M. I. (2019).Special education teacher's commitment to the implementation of the career transition program and its relationship with the administrators' distributive leadership.Faculty of Education, National University of Malaysia.Special Education International Conference (SEIC) 2019; September 25-27, 2019; Marriott Hotel, Putrajaya, Malaysia.

Yusoff, M. (2001).Qualitative Research: A Field Work Experience. 1st ed. Kuala Lumpur: University of Malaya Publisher.

Yusof, A. M., Ali, M. M, \& Salleh, A. M. (2013).Vocational Education Special Needs Students Meet the Job Market.Proceeding of the International Conference on Social Science Research. Malaysia: Penang. 1189- 1196. 